\title{
关于园林小品景观工程建设施工及其管理的探析
}

\author{
王元杰 陈红安 \\ 河南省豫建市政园林工程有限公司 \\ DOI:10.18686/bd.v2i4.1350
}

[摘要] 园林小品是城市景观环境中重要的构景要素之一, 并且园林小品景观工程建设要充分利用各个空间,合适、合理 地布置景观小品, 使之与植物、建筑、水体等有机地结合起来, 成为完整的景观。为了充分发挥其作用, 本文阐述了园林小品景 观工程的主要功能及其类型,对园林小品景观工程建设施工及其管理进行了探讨分析。

[关键词] 园林小品景观工程;功能; 类型;施工要点;施工要求;施工管理

园林小品景观工程除了能够美化环境,丰富园趣,还能 够让游人从中获得美的感受, 为了充分发挥园林小品景观 工程的作用以及保障园林小品景观工程质量, 以下就园林 小品景观工程建设施工及其管理进行了探讨分析。

\section{1 园林小品景观工程的主要功能及其主要类型}

1.1 园林小品景观工程的功能分析

(1)组景功能。园林小品在景观园林空间中,除具有自身 的使用功能外,更重要的作用是点缀装饰景观园林, 把外界 的景色组织起来, 引导人们由一个空间进人另一个空间, 起 着导向和组织空间画面的构图作用; 能在各个不同角度都 构成完美的景色,具有诗情画意。园林小品还起着分隔空间 与联系空间的作用, 使步移景异的空间增添了变化和明确 的标志。

(2)使用功能。使用功能是景观园林建筑小品的最基本 的功能。例如: 园灯用于照明,园椅园登用于休息,展览栏及 标牌用于提供游园信息,景观园林栏杆用于安全防护、分隔 空间等等。为了表达景观效果,景观园林建筑小品往往要进 行艺术处理,并且符合其使用功能以及在技术上、尺度上和 造型上的特殊要求。

(3)观赏功能。园林小品作为艺术品, 它本身具有审美价 值,其本身就是景观园林环境中的一景。运用小品的装饰性 能够提高其他景观园林要素的观赏价值, 满足人们的审美 要求,给人以艺术的享受和美感。

(4)渲染气氛。园林小品除具有组景,观赏作用外, 还把功 能作用比较明显的小品予以艺术化、景致化。一组休息的坐 登或一块标示牌,如果设计新颖,处理得宜,做成富有一定艺 术情趣的形式,会给人留下深刻的印象,使景观园林环境更 具感染力。

1.2 园林小品景观工程的类型

主要包括:第一、景观园林建筑小品: 以装饰景观园林 环境为主,注重外观形象的艺术效果,兼有一定使用功能。如 园灯、园椅、展览牌、景墙、栏杆等。第二、游彭性建筑: 有休 息、游赏等使用功能,具有优美的造型。如亭、廊、花架、榭、 舫、园桥等。第三、服务性建筑: 为游人在旅途中提供生活上 服务的设施。如小卖部、茶室、小吃部、餐厅、小型旅馆、则所
等。第四、开展文化娱乐活动用的设施: 如游船码头、游艺 室、俱乐部、演出厅、露天剧场、展览厅等。第五、公共管理用 设施: 主要由公园大门、办公室、实验室、栽培温室,动物园 还应有动物兽室等。第六、标志性建筑设施: 如一些假山、雕 塑、标识物等。

\section{2 园林小品景观工程建设的施工要点分析}

主要的园林小品景观工程建设的施工要点分析 : (1)园 亭工程施工要点。园亭作为园林小品工程中最基本的建筑 单元, 其形状一般小巧玲珑, 四面敞开, 通风透光, 是为满足人 们在旅游活动中的休憩、停歇、纳凉、避雨和观景之需。园亭 施工需要结合其平面形状、平面组合和屋顶形式等。中国古 建筑多是梁架体系的木结构,由木柱承重,因此平面和立面 的施工都较自由。屋顶的造型和曲线也可由人们的审美观 点和视觉需要来确定施工形式。传统园亭柱子有木、石两 种,用真材或砤仿制; 但屋盖变化多,如以硂代木,则所费工、 料均不合算, 效果也不甚理想。(2)景墙工程施工要点分析。 在处理基础墙与上部墙的错台上, 基础砖底撂底不能出错, 两边收退的大房角需保持一致, 在退出墙身前需查看轴线 和边线情况, 若出现较小的错误, 可在基础部分进行纠正。在 清水墙游丁走缝时, 景墙施工排砖需立缝排列均匀, 砌完一 步架高度, 每隔 $2 \mathrm{~m}$ 间距要在砖立楞处用托线板吊直弹线, 二步架往上继续吊直线粉线, 由底部往上的长度应保持一 致。上部分窗口的位置必须与下窗口的保持垂直。(3)花架工 程施工要点分析。景观园林花架是根据材料的性质,将其制 成一定的形状格架, 以供植物攀附的一种景观园林构筑物, 其能够镶嵌各类花卉。花架的应用较为广泛,材料多样化,主 要有竹木、石材、金属、混凝土等。若选择木料, 其品种、材 质、规格及数量都需要与施工标准相一致,木材不得出现腐 蚀或虫蛙,在连接的受剪面上不得出现裂纹,其防腐、防虫及 防火需要按照标准进行施工。(4)园林假山景观工程施工要 点。主要表现为:第一、木桩施工技术要点。园林假山景观施 工通常选用木桩作为其基础, 并多采用松木桩和杉木桩来 施工。施工时, 要将木桩顶面的直径控制在 $13 \mathrm{~cm}$ 左右, 将木 桩之间的距离控制在 $20 \mathrm{~cm}$ 左右, 在对其进行平面布置时通 常采用梅花形排列的方式。需要注意的是,务必将木桩打到 
硬土层上确保其稳固, 并使得木桩顶端能够露出水体底部 （露出的高度大约在 $10 \sim 30 \mathrm{~cm}$ )。木桩和木桩之间需要进行 一些列的处理,首先用块石将相邻木桩嵌紧,再将木桩的顶 部压上条石。上述工作全部完毕后才能在此基础上进行假 山景观形态山石的施工和修饰。第二、混凝土施工技术要 点。假山景观施工中通常选用混凝土或浆砌块石的形式作 为其基础, 通过这样形式的施工方式可以加快施工速度,加 大耐压强度,增强施工质量。如果是在水体中建造假山景观, 所选用的混凝土浆砌块石强度要为 C15, 也可以选用 C20 的速混凝土替代; 如果是在陆地上建造假山景观,所选用的 混凝土强度必须大于等于 $\mathrm{C} 10$ 。不论是水体中建造假山景 观还是陆地上建造假山景观,都必须根据山体的高度、体积 以及质量的不同, 土层的具体情况不同而确定是否需要格 外加人钢筋, 通过这样的方式来提高其强度。

\section{3 园林小品景观工程建设的施工要求及其施工管理}

3.1 园林小品景观工程建设的施工要求

(1)表现园林主题。公园类型多样,景观内容丰富,格调大 多倾向为自然、生态、休闲、娱乐等。公园绿地中的环境小品 主题明确,大多以公园的地域性、文化性为依托,选择烘托公 园氛围的特色小品。

(2)符合环境气氛和格调。恰当的色彩配以合适的形态, 在结合所塑造的形体功能时, 能恰如其分地传达美的讯号, 并满足人们的心理、生理需求。园林小品在色彩上首先要符 合不同类型公园的气氛和格调, 如严肃的纪念性公园场所 空间常用比较厚重的色彩传达一种庄严的情感, 而一些休 闲娱乐型的公园常常采用对比较强、艳丽的色彩。并且小品 色彩的设计还要考虑功能性的要求, 例如公园景观坐登是 为游人提供休咊的基础设施, 能够在人们缓解劳累之余提 供一个交流的空间,因此应采用古朴的自然色彩,如木材的 本色或石材的色泽。

(3)造型具有时代感。园林小品造型能够将人工与自然 浑成一体则是设计者们匠心之处。在成片种植场地中, 设以 体态形式美、内涵深刻、具有时代感、体现自然之趣的小物 件,会给生产绿地空间带来新奇的景象。

3.2 园林小品景观工程建设施工管理的分析
(1)施工准备管理。园林小品景观工程建设前,相关设计 人员必须将设计图纸对施工人员进行交底, 并交代施工过 程中要注意的细节。施工人员在原材料选用上需要选择符 合质量标准材料, 保证园林小品景观工程施工质量。施工前, 项目负责人要确保施工人员的专业技术能顺利完成小品工 程施工,并且保证设计符合标准且与景观园林整体相融合。

(2)施工过程中的管理。在园林小品景观工程施工的过 程中,无论是从施工机械还是原材料的使用上,都具有高要 求、高标准。园林小品大多为功能性和观赏性的小型建筑, 是基于景观园林工程基本完成后的精细施工，园林小品的 施工要考虑施工机械是否有足够的场地继续进行, 因此要 找到合适的施工机械设备及具有高技艺的设备操作人员。 施工中要保证原材料的合理利用, 并确保施工机械设备不 对原材料产生损坏。施工过程中应加强管理,不仅施工人员 要管理好机械和原材料, 减少其损坏率, 项目负责人也要做 好对施工人员的管理,确保工程施工的进度和施工质量。

(3)竣工后的管理。园林小品景观工程施工完成之后, 需 要专业人员对工程进行统一的质量评估, 发现施工问题所 在,提出施工建议,并且及时进行改进, 确保施工质量符合规 定。对完工的园林小品, 要加强对其进行保护, 以保证景观园 林工程质量。

\section{4 结束语}

综上所述, 园林小品景观工程作为园林工程建设的重 要环节,其施工质量会影响到园林建设效果和实用性, 因此 为了充分发挥园林小品景观工程的功能, 必须加强对其施 工与管理进行分析。

\section{参考文献:}

[1]伍威,王治昕.园林工程中的小品施工技术初探[J]. 农村经济与科技,2017,28(07):266-267.

[2]王义东.园林工程中建筑小品施工技术探讨 [J]. 门 窗,2016,(12):85.

[3]李俊.简议园林小品工程的施工及其管理[J].建材 与装饰,2016,(21):80-81.

[4] 赖建山。园林中小品土建施工质量控制策略探究 [J].江西建材,2016,(16):215+219. 